\title{
Hartz IV and educational attainment: Investigating the causal effect of social benefit reform on intergenerational inequalities in Germany ${ }^{1}$
}

\author{
Nhat An Trinh* \\ [This is an outdated version. For the most recent version, please visit \\ http://doi.org/10.31235/osf.io/kpxhf]
}

June 2021

\begin{abstract}
This study examines how far radical and still contested changes to Germany's unemployment and social benefit system in 2005 affected the intergenerational transmission of disadvantage for children of benefit recipients. Using differencein-differences estimation and data from the Socio-Economic Panel, I examine whether inequalities in secondary school attainment increased after the implementation of the so-called 'Hartz IV' reform. The findings suggest that children whose parents receive the newly created scheme ALGII instead of Arbeitslosenbilfe for unemployment assistance experienced a significant and considerable drop in their chances to attend the Gymnasium. Changes in parents' socio-demographic characteristics due to stricter eligibility criteria and lower household incomes as a result of lower benefit levels account for the observed decline. By contrast, reductions in parental life satisfaction related to increased benefit conditionality and stigma are unlikely to mediate the reform's documented effects. Focussing on an important outcome in Germany's highly stratified educational system, the study is the first to provide evidence on the intergenerational effects of Hartz IV, shedding light on the role of social security and welfare institutions in the transmission of inequalities from parents to their children.
\end{abstract}

Keywords: Educational attainment, educational transition, intergenerational inequality, social mobility, parental benefit receipt, parental unemployment, Hartz IV, ALG II, natural experiment, policy evaluation, Germany

\footnotetext{
${ }^{1}$ I am grateful to Erzsébet Bukodi, Caspar Kaiser, Brian Nolan, and Aaron Reeves for their helpful comments and suggestions.

*nhatan.trinh@spi.ox.ac.uk, Department of Social Policy and Intervention, Wolfson College, University of Oxford.
} 
During the early 2000s, Germany's labour market and social protection system underwent radical reorganisation that led to an unprecedented shift from conservative Bismarckian principles of social insurance towards greater activation and employment flexibilization. Although more than a decade has passed, the so-called 'Hartz reforms' remain contested and are a recurring subject of public and political debate (Süddeutsche Zeitung 2019; Der Spiegel 2020).

While Hartz I-III comprised the introduction of new and the reform of existing active labour market policies, Hartz IV modified unemployment and social benefit regulations. Its main feature was to merge unemployment assistance for the long-term unemployed and social assistance for those in need into one benefit scheme called Arbeitslosengeld II. As a result, individuals who are unemployed for more than a year lost their insurance-based claim to earnings-related benefits. Unemployment assistance is now only provided if household incomes fall below subsistence level and has become highly conditional on active job search and participation in active labour market programmes. In other words, Hartz IV created a cleavage between the unemployed, dividing them into an exclusive, well-protected group covered by earnings-related benefits on the one hand, and a group covered only by flat-rate basic income support on the other hand. The reform thus led to the generation of new inequalities, and has been widely discussed as a contributing driver of labour market dualization in Germany (Clasen and Clegg 2006; Palier and Thelen 2010; Eichhorst and Marx 2011).

Inequalities within one generation predict inequalities within the next generation. Across postindustrial societies, socio-economic disadvantage is passed from parents to their children (Ermisch, Jäntti, and Smeeding 2012; Breen and Müller 2020). In Germany, the association between individuals' social origin and social destination seems particularly strong, and levels of intergenerational mobility are comparatively low (Bukodi, Paskov, and Nolan 2019). By removing earnings-related benefits for the long-term unemployed and increasing benefit conditionality for those in need, it seems likely that Hartz IV not only affected the generation of current workers but also the outcomes and opportunities of their offspring.

Still, we lack evidence on such intergenerational effects of the reform. These effects might be particularly detrimental and arguably unjust, as children who experience parental unemployment form already a vulnerable and disadvantaged group. Previous studies show that children with unemployed parents have lower levels of educational attainment compared to children whose parents work (Brand 2015; Coelli 2011; Kalil and Wightman 2011; Lohmann and Groh-Samberg 2017; Lindemann and Gangl 2019). Lower educational attainment, in turn, translates into poorer labour market outcomes and life chances more broadly. It is therefore vital to know whether Hartz IV reinforced the transmission of disadvantage across generations, thereby widening intergenerational inequalities.

By taking up this task, this study makes two contributions to the literature. Empirically, it is the first that expands the existing micro- and macro-economic evidence on the reform's effect on unemployment levels and duration (Krause and Uhlig 2012; Launov and Wälde 2013; Hochmuth et al. 2021), job matching efficiency (Hertweck and Sigrist 2012), and wages (Bradley and Kügler 2019) by analyses that focus on inequality-generating processes that occur within families rather than the labour market. Investigating the outcomes of children of benefit recipients allows to 
identify long-lasting social consequences, which might have neither been anticipated nor intended when the reform was first devised.

Theoretically, the study sheds light on the role of institutions in fostering social mobility and equality of opportunity. To date, research struggles to pinpoint the degree to which welfare states and social security systems compensate or reinforce intergenerational inequalities. Most studies adopt comparative, cross-national designs to investigate the association between public institutions and the transmission of disadvantage across generations (Beller and Hout 2006; Esping-Andersen 2014; Bukodi et al. 2017; Lindemann and Gangl 2020). Unfortunately, however, these do not allow for a robust estimation of causal relationships given issues of unobserved heterogeneity. The small number of studies that are able to exploit exogenous variation are limited to assessing the impact of educational systems (Betthäuser 2017; Pischke and von Wachter 2008; Sturgis and Buscha 2015). Whether and how characteristics of social security systems are causally linked to levels of intergenerational inequality seems therefore unclear.

The German Hartz IV reform offers a unique opportunity to study the impact of the social security system on the intergenerational transmission of inequality based on a natural experiment. In this study, I evaluate the reform's effects, focussing on the educational attainment of children of unemployment and social benefit recipients. Specifically, I examine whether the reform negatively affected the educational attainment of children with parents receiving unemployment assistance, i.e. benefits aimed at supporting the long-term unemployed. Given that in Germany the transition from primary to secondary school is highly predictive of future training and labour market opportunities, I focus on secondary school track attainment as the educational outcome of interest.

The next section outlines in greater detail Germany's unemployment and social benefit system before and after the implementation of Hartz IV. I then elaborate on why the reform likely led to lower educational attainment for children with parents receiving unemployment assistance. The subsequent section describes the analytical strategy followed by the presentation of the empirical findings. A discussion of their implications for future research and policymaking is provided in the final section.

\section{The German unemployment and social benefit system before and after 2005}

In the comparative welfare state literature, Germany is considered a key representative of the conservative welfare state regime (Esping-Andersen 1990). Organised based on the principle of social insurance, its welfare institutions centre around the worker and are underpinned by strong tripartite partnerships between employees, employers, and the state.

Until the early 2000s, Germany's protection of the unemployed consisted of two pillars (Hassel and Schiller 2010). Both aimed at safeguarding the individual from experiencing a drop in living standards due to unemployment. The first pillar was Arbeitslosengeld, i.e. benefits from unemployment insurance. These were generally paid for 12 months to individuals with social insurance contributions of at least 12 months during a qualifying period of 2 years before becoming unemployed. Depending on overall contributions, older individuals could even receive benefits for up to 36 months. Benefit levels were equivalent to 67 and 60 percent of previous earnings for 
individuals with and without children, respectively. The second pillar was Arbeitslosenhilfe, i.e. taxfunded unemployment assistance. Benefits from unemployment assistance were in principle unlimited and paid to individuals, whose claim to Arbeitslosengeld expired. They were therefore also conditional on previous social insurance contributions. Payments could cease if recipients repeatedly refused to accept work that was comparable to their previous employment or current benefit levels. Replacement rates amounted to 57 and 53 percent for individuals with and without children, respectively (Bäcker and Koch 2004).

Implemented on January 1, 2005, the Hartz IV reform combined the second pillar of unemployment protection with flat-rate basic income support for those in need. Before the reform, Sozialbilfe, i.e. tax-funded social assistance, provided all individuals in need who were not covered by unemployment insurance with a minimum social security net. Its main purpose was to reduce poverty and to guarantee a legally defined socio-cultural subsistence level within households. Thus, individuals received benefits only upon passing a means test, and refusal to take up work was strictly sanctioned with benefit cuts. There was hence a clear difference in benefit generosity and conditionality for individuals whose entitlement to social benefits was based on previous employment and social contribution records vis-à-vis financial hardship.

After the reform, this distinction eroded. Since 2005 entitlement to earnings-related benefits ends with the expiration of Arbeitslosengeld, which older workers can now receive for a shorter maximum duration of 18 months (Bäcker 2017). Individuals who remain unemployed for a longer period of time are only eligible for means-tested, flat-rate basic income support. The main objective behind this dramatic policy shift was to reduce long-term unemployment and welfare dependance (Jacobi and Kluve 2006). During the 1990s, the proportion of long-term unemployed among all unemployed had increased to over 50 percent (OECD 2020). For this purpose, Hartz IV also redefined the category of people in need and divided them into two groups based on their ability to work (Goebel and Richter 2007). Individuals who can work for at least 3 hours per day need to apply to the newly created scheme Arbeitslosengeld II (ALGII). ${ }^{2}$ Individuals who cannot work for at least 3 hours per day, and who do not share a household with someone eligible for ALGII, continue to receive Sozialbilfe. While benefit levels are similar, the main difference between the two schemes is that $A L G I I$ is highly conditional on active job search and participation in activation measures as well as related labour market programmes. Accordingly, harsh sanctions for non-compliance were introduced for recipients of $A L G I I .{ }^{3}$ By contrast, sanctions for recipients of Sozialbilfe were omitted after the reform as they are no longer subject to labour market integration. Table 1 gives an overview of the unemployment and social benefit schemes that were in place before and after the introduction of the reform.

[Table 1]

\footnotetext{
${ }^{2}$ It is important to note that $A L G I I$ is therefore not only accessible to individuals without employment but can also be claimed by those on low incomes as an in-work benefit (Eichhorst and Marx 2011).

${ }^{3}$ Sanctions are divided into three steps. Refusal to accept a job offer could be penalised with 30 percent benefit cuts if occurred for the first time, and 60 percent benefit cuts if occurred for the second time. Additional violations within the same year could lead to loss of the entire benefit. Moreover, recipients could be sanctioned with 10 percent benefit cuts if they miss appointments at the public employment agency. In November 2019, the Federal Constitutional Court ruled that sanctions of more than 30 percent are unconstitutional (Der Tagesspiegel 2019).
} 
Sociological research consistently shows that individuals' education is substantively determined by their social origin (Shavit and Blossfeld 1993; Breen and Müller 2020), and distinguishes between so-called primary and secondary effects (Boudon 1974). Primary effects refer to all those aspects of social origin that have a direct influence on individuals' educational outcomes. Secondary effects refer to the impact of social origin on educational choices. In Germany, the association between social origin and education appears particularly strong (Pollak and Müller 2020). This is because ability-based sorting into different school tracks that vary in curriculum, academic outlook and length occurs early and is rarely reversible, reinforcing both primary and secondary effects (Neugebauer et al. 2013).

Accordingly, children living in families that receive unemployment or social benefits tend to fare worse than children living in families that do not receive such benefits. This is because benefit receipt strongly relates to parental employment status, which in turn is highly predictive of children's educational attainment (Becker and Nietfeld 1999; Lohmann and Groh-Samberg 2017; Lindemann and Gangl 2019). The reform therefore acted on a group that is disadvantaged already. However, by reducing benefit generosity, increasing benefit conditionality, and tightening benefit eligibility, Hartz IV decreased resources among recipients of unemployment assistance for their children's education even further. Particularly, these parents are likely to have experienced a decline in their financial, psychological as well as socio-cultural resources, all of which are important for children's educational attainment.

Regarding parents' financial resources, Goebel and Richter (2007) show that more than 50 percent of individuals who switched from Arbeitslosenhilfe to ALGII experienced a loss in income. In the first year of the reform two in three households receiving ALGII had incomes below 60 percent of median income, and the poverty gap ${ }^{4}$ was with 18.5 percent almost twice as high as the poverty gap for households receiving Arbeitslosenbilfe one year before. Receiving unemployment assistance has therefore become more strongly associated with economic disadvantage after the reform. As a result, parents receiving unemployment assistance have fewer means to advance their children's learning and performance in school through buying books or other learning material and are less likely to afford private tutoring lessons, summer schools, and extra-curricular activities (Duncan and Brooks-Gunn 1997; Kaushal, Magnuson, and Waldfogel 2011). Given their now lower incomes and the associated economic insecurities, their ability to financing long periods in education and training seems also reduced. They are hence more likely to struggle with the decision to enrol their children into the academic secondary school track that takes considerably longer to complete than any of the vocational secondary school tracks.

With respect to parents' psychological resources, evidence exists showing that the reform turned the receipt of unemployment assistance into a more taxing experience, aggravating the welldocumented negative effects of unemployment on individuals' wellbeing (Clark 2003; Oesch and Lipps 2013). Deter (2020), for example, reports that Hartz IV led to lower levels of life satisfaction among the long-term unemployed. As explained above, recipients of ALGII are strictly monitored by public employment agencies in their efforts to find work and are required to participate in active

\footnotetext{
4 The poverty gap measures the extent to which individuals' income fall short from the poverty line. In this case, it measures the percentage by which individuals' income are below 60 percent of median income.
} 
labour market programmes. Additionally, policymakers used language of blame and contempt, creating a dooming narrative around social benefit recipients, when introducing the Hartz reforms to the public (Fohrbeck, Hirseland, and Lobato 2014). ${ }^{5}$ Parents receiving ALGII are thus exposed to greater stress as well as stigmatisation compared to parents receiving Arbeitslosenbilfe. This in turn is likely to contribute to family instability and further limit their ability to make important investments into their children's education. Parental emotional wellbeing has been found to create a stable home environment and to be conducive to parents' capacity to offer effective help with homework (Murray et al. 2006) as well as to monitor their children's school-related activities and overall progress (Bratti and Mendola 2014).

Finally, the introduction of strict means-testing implies that only a small, arguably more adversely selected group of parents remained eligible for unemployment assistance after the reform. Parents receiving ALGII could therefore lack certain socio-cultural resources to help their children do homework, navigate the educational system or develop certain behavioural patterns and other noncognitive skills that are rewarded by teachers and schools (Bourdieu 1977; Farkas 2003; Jaeger 2009). Moreover, it has been suggested that families primarily opt for educational trajectories that allow children to attain similar socio-economic positions as their parents (Breen and Goldthorpe 1997). Given that parents receiving ALGII are more socio-economically deprived than parents receiving Arbeitslosenbilfe, the former might then also be less ambitious in promoting their children's academic achievements as lower educational attainment is likely to suffice for their children to avoid intergenerational downward mobility.

There are hence three pathways through which Hartz IV could lead to lower educational attainment for children with parents on unemployment assistance: parents have fewer (1) financial resources due to reduced benefit levels, (2) psychological resources due to increased benefit conditionality and stigma regarding benefit receipt, and (3) socio-cultural resources due to harsher eligibility criteria and means-testing. Thus, while (1) and (2) recognise a worsening in the conditions of families receiving unemployment assistance, (3) highlights a general change in their composition towards the more disadvantaged.

\section{$4 \quad$ Analytical strategy}

Data

All analyses are based on the Socio-Economic Panel (SOEP), which is Germany's largest representative, longitudinal survey. Every year around 30,000 individuals in ca. 11,000 households are interviewed on different aspects of their life including education, labour market participation, economic conditions, and family composition. The main analytical sample consists of children who transitioned from primary to secondary school between 2001-2010 and is split symmetrically into a pre- and post-reform group. For 2,462 children this transition is directly observed. Using information on average transition age by birth year and state of residence, I further impute year of transition for another 327 children, who were already in secondary school by the time of the

\footnotetext{
${ }^{5}$ In colloquial language, the term "hartzen" even developed, referring to people being lazy, free-riding, and passively dependent on social welfare.
} 
survey. ${ }^{6}$ Information on these children's education is then combined with data on parental benefit receipt from the year preceding their transition from primary to secondary school. Parental information for the pre- and post-reform group refer to the period 2000-2004 and 2005-2009, respectively. Children are linked to their parents using identifiers provided in the annual childspecific files. Thus, rather than using identifiers on their biological parents, I match children to those parents with whom they live and interact on a daily basis.

\section{Key variables}

The transition from primary to secondary school constitutes a critical moment in the educational trajectories of German children. Due to rigid tracking practices, type of secondary school has longlasting consequences on academic achievements and labour market careers. Traditionally, three types of secondary schools exist in the German educational system. The lower (Hauptschule) and intermediate (Realschule) secondary schools provide vocational education, whereas the higher secondary school (Gymnasium) focusses more on academic education. However, over the past decades, this three-track system increasingly moved towards a two-tiered system that was accompanied by the creation of comprehensive schools offering different school leaving degrees under the same roof (Becker, Neumann, and Dumont 2017; Blossfeld 2018). I therefore measure children's educational attainment using a binary variable that takes the value 1 if they enter the Gymnasium, and 0 if they attend any of the other secondary school types. Despite recent changes to Germany's secondary school structure, the Gymnasium has kept its status and prestige, and exists in all federal states as the only school that exclusively offers the university entrance exam 'Abitur'. It therefore provides direct access to university training and is also increasingly required for more prestigious post-secondary vocational programmes.

Parental benefit receipt in a given year is measured using information from both the annual individual as well as household questionnaires. I distinguish between four categories: (1) no benefits, (2) unemployment benefits, (3) unemployment assistance, and (4) social assistance. Arbeitslosengeld is coded as unemployment benefits, Arbeitslosenbilfe is coded as unemployment assistance, and Sorialhilfe is coded as social assistance. Given that ALGII is not only accessible to the unemployed but also to workers on low incomes, I use information on past benefit receipt to assign recipients of ALGII the relevant benefit category. Recall that Arbeitslosenbilfe was only paid to those whose claim to Arbeitslosengeld expired. Parents who reported Arbeitslosengeld immediately before receiving ALGII are therefore comparable to recipients of Arbeitslosenbilfe. Accordingly, ALGII is coded as unemployment assistance if it was directly preceded by Arbeitslosengeld in the previous four years ${ }^{7}$, or by Arbeitslosenhilfe. By contrast, parents who did not receive Arbeitslosengeld before obtaining $A L G I I$ in the stated period are identified as recipients of social assistance.

\footnotetext{
${ }^{6}$ In the pre- and post-reform group, the proportion of children, for whom year of transition from primary to secondary school is imputed, is 13.32 percent and 9.58 percent, respectively.

${ }^{7}$ For the majority of children, this period covers the entire time spent in primary education. Except for some federal states such as Berlin and Brandenburg, where the transition occurs after six years in primary school, the transition generally occurs after grade four. It thus seems plausible that changes from Arbeitslosengeld to ALGII have the greatest impact on secondary school transitions during this period. In addition, parents who receive $A L G I I$ for more than four years, regardless of whether this was preceded by Arbeitslosengeld or not, likely constitute a rather specific group, and are more likely to be comparable with recipients of social assistance than unemployment assistance.
} 
Parents might receive benefits from multiple schemes during a year. Where this is the case, parents are considered receiving social assistance if it was claimed for at least three months. Parents are considered receiving unemployment assistance if unemployment assistance was received for at least three months and social assistance was not reported for more than two months in the year in question. Similarly, parents are considered receiving unemployment benefits if they were received by one parent for at least three months, and none of the other benefits were reported for the same minimal amount of time. Children are considered living in no-benefit households if neither parent received social assistance, unemployment assistance, or unemployment benefits for more than two months. Periods of benefit receipt of less than three months appear rather transitional and are therefore unlikely to bear significant consequences for children's educational attainment. The four benefit categories are thus mutually exclusive, comparable across the pre- and post-reform period, and comprise all children who made the transition from primary to secondary school during the stated observation window.

\section{Modelling}

To identify the effect of the Hartz IV reform on the educational attainment of children of unemployment assistance recipients, I adopt a quasi-experimental research design based on difference-in-differences (DID) estimation (Angrist and Pischke 2008). Although the reform was implemented simultaneously across Germany and thus affected the entire population at the same time, it seems plausible that families that did not receive any of the benefits discussed were least affected by the reform. Children living in such families are therefore taken as reference group against which pre- and post-reform differences in Gymnasium attendance for children with parents receiving unemployment assistance are compared. For completeness and to account for potential spill-over effects, I also compare pre- and post-reform differences in Gymnasium attendance between children living in families, where no parent receives benefits, and where unemployment benefits or social assistance are received.

Using ordinary-least-squares regression $(\mathrm{OLS})^{8}$, I estimate linear probability models of the following form:

$$
\begin{aligned}
\pi_{i t}=\alpha & +\beta_{b} \text { BEN }_{i b t-1}+\sigma R E F \text { ORM }_{t-1}+\lambda_{b}\left(\text { BEN }_{i b t-1} \times \text { REFORM }_{t-1}\right) \\
& +\varphi X_{i t-1}+\phi\left(X_{i t-1} \times \text { REFORM }_{t-1}\right)+\tau_{t-1}+\varepsilon_{i t}
\end{aligned}
$$

where $\pi_{i t}$ indicates whether child $i$ entered the Gymnasium after primary school in year $t$. $B E N_{i b t-1}$ denotes a set of dummies for parental benefit receipt $b$ in year $t-1$, i.e. one year before the child's transition. REFORM $M_{t-1}$ is a dummy that indicates whether parental benefit receipt is observed before or after the reform. It takes the value 0 if parental benefit receipt is observed in year $t-1$ $<2005$, and 1 otherwise. $B E N_{i b t-1} \times R E F O R M_{t-1}$ identifies whether the association between children's Gymnasium attendance in $t$ and parents' receiving benefit receipt $b$ in $t-1$ changed after the reform relative to children whose parents did not receive any benefits. $X_{i t-1}$ and

\footnotetext{
${ }^{8}$ For ease of interpretation, and in order to compare coefficients across models (cf. Mood 2010; Breen, Karlson, and Holm 2013), OLS is preferred over logistic regression. Results are however similar when using the latter (see appendix Table A1).
} 
$X_{i t-1} \times R E F O R M_{t-1}$ denote a vector of covariates and their interaction with the reform dummy, respectively. $\tau_{t-1}$ is a year fixed-effect ${ }^{9}$ and $\varepsilon_{i t}$ is the error term.

To examine whether recipients of unemployment assistance became a more negatively selected group leading to a decline in their socio-cultural resources, I include terms for a range of sociodemographic characteristics. These are the child's age at the transition, sex, migrant background as well as the number of children younger than 15 in the household, whether living with a single parent, parental age(-squared), parental education, parental class, and parental self-rated health in $t-1$. In cases where mother's and father's age, education or class differ, the higher value is taken. In cases where mother's and father's report different levels of health, the lower value is taken. To test for the mediating effects of reduced parental financial and psychological resources, I further include terms for (log) net equivalised household income (including imputed rent) in 2000 Euros and parental life satisfaction in year $t-1$. Life satisfaction is measured on a scale from 0 to 10 , where higher values indicate higher life satisfaction. In cases where mother's and father's life satisfaction differ, the lower value is taken.

Moreover, all models control for the state where the transition to secondary school took place to account for state-specific heterogeneities in Gymnasium attendance. ${ }^{10}$ Cross-sectional weights that refer to year $t$ are used and rescaled such that transition cohorts have the same size. The weighted number of children is therefore equal in the pre- and post-reform group. Table 2 displays the unweighted distributions of all variables included in the analysis, separately for the pre- and postreform samples.

[Table 2]

\section{$5 \quad$ Empirical findings}

Table 3 presents OLS estimates for attending the Gymnasium for children, who transition to secondary school between 2001 and 2010 in Germany. Column 1 shows the main effects of parental benefit receipt, controlling only for year and state fixed-effects. As argued earlier, children living in families that receive unemployment or social benefits have significantly lower chances to attend the academic school track than children from no benefit backgrounds. On average, children whose parents receive unemployment benefits or assistance are 18 percentage points less likely to go to the Gymnasium. Having parents who receive social assistance is associated with an even larger gap of 23 percentage points. I hence observe generally poorer educational outcomes for children of benefit recipients.

In column 2, the reform interaction is included. The main effects for parental benefit receipt now denote differences in Gymnasium attendance during the pre-reform period, while the interactions with the reform dummy identify changes in these differences after the introduction of Hartz IV.

\footnotetext{
${ }^{9}$ In order to achieve identification of the reform dummy, the sums of coefficients referring to the pre-reform period, i.e. years 2000-2004, and of the coefficients referring to the post-reform period, i.e. years 2005-2009, are constrained to zero.

${ }^{10}$ For children, for whom year of transition is imputed, state of residence for the year that comes closest to the transition is used.
} 
Consequently, their sums indicate post-reform inequalities in the probability to attend the Gymnasium. In line with expectations, I observe a sizable drop in the probability to attend the Gymnasium for children whose parents receive unemployment assistance. For children who made the transition before 2006, parental unemployment assistance receipt is associated with a 9 percentage points lower chance to attend the academic track. The coefficient is however not statistically significant. After the reform, the gap between these children and those living in no benefit families more than triples, increasing to 34 percentage points.

By contrast, the interactions for parental unemployment benefit and social assistance receipt are not statistically significant and rather moderate in size. Before the reform, parental unemployment benefit receipt is more strongly associated with children's education than parental unemployment assistance receipt. Recall that parents receiving unemployment benefits have just lost their job, while parents receiving unemployment assistance are unemployed for at least 12 months. Although unemployment assistance has a slightly lower replacement rate, it is paid indefinitely and therefore provides economic security nonetheless. Given such economic security, family stability and parentchild interactions might, following an initial shock, improve over time despite longer periods of parental unemployment. Thus, educational disadvantages are plausibly smaller for children whose parents receive Arbeitslosenbilfe than for those whose parents receive Arbeitslosengeld. Given that families receiving Sozialhilfe struggle with financial insecurities and hardship the most, it also seems reasonable that parental social assistance receipt most strongly predicts children's transition to the Gymnasium before the reform.

In column 3, terms for socio-economic characteristics are added. The interaction between the reform dummy and parental unemployment assistance decreases by 2.3 percentage points (13 percent) and remains statistically significant. Net of differences in migration background, family composition as well as parental age, education, social class and health, the gap in Gymnasium attendance for children whose parents receive unemployment assistance still amounts to 18 percentage points after the reform. Changes in the composition of these parents due to stricter eligibility criteria and means-testing thus drive the observed reform effect only in part.

Adding a term for $(\log )$ household income in column 4 leads to a more substantive reduction in the size of the interaction and turns the coefficient statistically insignificant. The coefficient decreases by 10 percentage points (46 percent) between columns 3 and 4 . Children whose parents receive $A L G I I$ are now only 4.5 percentage points less likely to attend the academic track compared to their peers living in no benefit families. As seen in Figure 1, this gap is yet no longer statistically significant. Accounting for parental life satisfaction in column 5 does not change the interaction much further. The estimated post-reform difference associated with parental unemployment assistance receipt remains essentially unchanged. I therefore find evidence that Hartz IV led to lower educational attainment for children whose parents receive unemployment assistance also by worsening their financial conditions. The current results do not point towards a role of parental psychological resources in mediating the reform's adverse impact. Lower benefit levels alongside stricter eligibility criteria and means-testing appear to account for the majority of the observed increase in educational inequalities following the reform.

[Figure 1] 
For unbiased identification, the DID estimator rests on the so-called 'parallel trends assumption' (Angrist and Pischke 2008). This assumption states that pre-treatment trends in the outcome of interest are similar for the two groups that are compared against one another. Accordingly, the probability to attend the Gymnasium for children of unemployment assistance recipients and those who do not receive benefits should follow similar trends before the introduction of Hartz IV.

To test the validity of this assumption, I conduct a series of additional robustness checks. First, I run the above model on the pre-reform sample only and further interact the year fixed-effects with parental benefit receipt. The results are shown in Table A2 (appendix). None of the interactions with parental unemployment assistance receipt is statistically significant. The same applies if I specify a linear year trend (results not shown), providing supportive evidence that trends in Gymnasium attendance did not differ between children with parents receiving unemployment assistance and those with parents not receiving benefits before the reform.

Next, I pretend that the reform was already implemented in 2001 and assign transition cohorts to the pre- and post-reform group accordingly. Prior to Hartz IV, Germany's unemployment and social benefit system was modified for the last time in 1997. Children who transitioned to secondary school between 1998-2001 are hence assigned to the pre-reform group, whereas children who made the transition between 2002-2005 form the post-reform group. Yet, this placebo analysis not only simply tests whether trends in Gymnasium attendance started to diverge before 2005. As mentioned in the introduction, Hartz IV was part of an entire reform package ("Agenda 2010"). Re-running the analyses with this placebo thus also inspects whether the observed rise in educational inequalities was actually caused by any of the other three reforms that were introduced before.

Analogously, I check whether the observed changes in Gymnasium attendance among children of unemployment assistance recipients were driven by some other event that occurred after 2005 (e.g. financial crisis). For this second placebo analysis, I pretend that the reform was implemented in 2010. Children who transitioned to secondary school between 2006-2010 are hence assigned to the pre-reform group and children who made the transition between 2011-2013 are assigned to the post-reform group. ${ }^{11}$

Table A3 (appendix) shows no statistically significant reform interaction for either placebo test. For both reform placebos, the coefficients are of negligible size and not statistically different from zero. I therefore do not find indication for a violation of the parallel trends assumption, nor evidence that the observed decline in the educational attainment of children whose parents receive unemployment assistance was driven by anything else other than Hartz IV.

\footnotetext{
11 Appendix Figure A1 gives an overview of the different transition cohorts that are used as pre- and post-reform groups in the main and auxiliary analyses.
} 
This study is the first to provide empirical evidence on the causal impact of the Hartz IV reform on the intergenerational transmission of disadvantage in Germany. I find that children from unemployment assistance backgrounds experienced a significant and considerable drop in their chances to attend the academic secondary school track after radical alterations to the unemployment and social benefit system were introduced in 2005. More attention hence needs to be directed towards the role played by welfare and social security systems in shaping opportunities and life chances for both current and future generations.

For researchers, this means in particular to extend the present analyses to different contexts and settings. As with any quasi-experimental study, the current findings are limited in their external validity and cannot be generalised outside the particular case of the German Hartz IV reform. It is hence crucial to know whether similar effects will be observed when different welfare institutions and benefit schemes, which differ in purpose and design, are put under scrutiny in different countries and time periods.

Moreover, data limitations constrain the current study's ability to fully uncover all the mechanisms through which Hartz IV led to the observed reductions in children's educational attainment. While I find evidence in support of two suggested mechanisms, 50 percent of the reforms' observed effects are still left to be explained by factors other than adverse selection or reductions in parents' financial means. Future research may therefore benefit from exploring other mechanisms through which Hartz IV, and other unemployment and social benefit schemes, could act on parents' capacity to advance their children's education. The inclusion of more comprehensive measures of emotional wellbeing that go beyond life satisfaction, and information on mothers' and fathers' personality traits, behaviour, or parenting styles might be helpful to more precisely determine the significance of parental psychological resources (or lack thereof) in mediating the effects of social security systems. Looking at child outcomes other than education might be another useful extension.

For policymakers, the findings highlight that decisions about benefit levels, conditionality and eligibility have far-reaching consequences. Welfare and social security systems can provide strong protection for workers and their families against the risk of unemployment, that are known to adversely interfere with children's development and socio-economic prospects. Prior to the introduction of Hartz IV, children growing up in families where parents received unemployment assistance did not fall behind their peers and had similar chances to go to the Gymnasium as children living in no-benefit households. After the reform, however, these children were on par, if not worse off, than children coming from social assistance backgrounds. Replacing Arbeitslosenbilfe with ALGII thus appears to have undermined the protective function of the conservative welfare state, leading to the reinforcement of disadvantage at the bottom of society. Some may consider this problematic. Whether overall reductions in long-term unemployment and welfare dependence are able to justify the observed decreases in the educational attainment of children, whose parents require income support, is therefore subject to moral and political deliberation. The present analyses act as an important reminder that changes to social institutions that directly affect people's livelihoods require careful consideration. Balancing trade-offs may go beyond a single generation. 


\section{References}

Angrist, Joshua, and Jörn-Steffen Pischke. 2008. Mostly Harmless Econometrics. Princeton University Press.

Bäcker, Gerhard. 2017. Chronologie Gesetəlicher Neuregelungen: Arbeitsförderung/SGB III \& Arbeitsrecht 1998-2016. Universität Duisburg-Essen.

Bäcker, Gerhard, and Angelika Koch. 2004. Absicherung Bei Langzeitarbeitslosigkeit: Zentrale Unterschiede Zwischen Zukünftigem Arbeitslosengeld II, Bisheriger Arbeitslosenbilfe Und Bisheriger Sozialhilfe. Universität Duisburg-Essen.

Becker, Michael, Marko Neumann, and Hanna Dumont. 2017. 'Recent Developments in School Tracking Practices in Germany: An Overview and Outlook on Future Trends'. ORBIS SCHOLAE 10 (3): 9-25. https://doi.org/10.14712/23363177.2017.8.

Becker, Rolf, and Markus Nietfeld. 1999. 'Arbeitslosigkeit Und Bildungschancen von Kindern Im Transformationsprozeß. Eine Empirische Studie Über Die Auswirkungen SozioÖkonomischer Deprivation Auf Intergenerationale Bildungsvererbung’. Kölner Zeitschrift Für Soziologie Und Sozialpsychologie 51 (1): 55-79.

Beller, Emily, and Michael Hout. 2006. 'Welfare States and Social Mobility: How Educational and Social Policy May Affect Cross-National Differences in the Association between Occupational Origins and Destinations'. Research in Social Stratification and Mobility 24 (4): 353-65. https://doi.org/10.1016/j.rssm.2006.10.001.

Betthäuser, Bastian. 2017. 'Fostering Equality of Opportunity? Compulsory Schooling Reform and Social Mobility in Germany'. European Sociological Review 33 (5): 633-44. https://doi.org/10.1093/esr/jcx066.

Blossfeld, Pia Nicoletta. 2018. Changes in Inequality of Educational Opportunity. Wiesbaden: Springer Fachmedien Wiesbaden. https://doi.org/10.1007/978-3-658-22522-3.

Boudon, Raymond. 1974. Education, Opportunity, and Social Inequality: Changing Prospects in Western Society. New York: Wiley.

Bourdieu, Pierre. 1977. 'Cultural Reproduction and Social Reproduction'. In Knowledge, Education, and Cultural Change, edited by Richard Brown, 71-112. London: Tavistock.

Bradley, Jake, and Alice Kügler. 2019. 'Labor Market Reforms: An Evaluation of the Hartz Policies in Germany'. European Economic Review 113 (April): 108-35. https://doi.org/10.1016/j.euroecorev.2018.12.008.

Brand, Jennie E. 2015. 'The Far-Reaching Impact of Job Loss and Unemployment'. Annual Review of Sociology 41 (1): 359-75. https://doi.org/10.1146/annurev-soc-071913-043237.

Bratti, Massimiliano, and Mariapia Mendola. 2014. 'Parental Health and Child Schooling'. Journal of Health Economics 35 (May): 94-108. https://doi.org/10.1016/j.jhealeco.2014.02.006.

Breen, Richard, and John H. Goldthorpe. 1997. 'Explaining Educational Differentials Towards a Formal Rational Action Theory'. Rationality and Society 9 (3): 275-305. https://doi.org/10.1177/104346397009003002.

Breen, Richard, Kristian Bernt Karlson, and Anders Holm. 2013. 'Total, Direct, and Indirect Effects in Logit and Probit Models'. Sociological Methods \& Research 42 (2): 164-91. https://doi.org/10.1177/0049124113494572.

Breen, Richard, and Walter Müller, eds. 2020. Education and Intergenerational Social Mobility in Europe and the United States. Studies in Social Inequality. Stanford, California: Stanford University Press. 
Bukodi, Erzsébet, Ferdinand Eibl, Sandra Buchholz, Sonia Marzadro, Alessandra Minello, Susanne Wahler, Hans-Peter Blossfeld, Robert Erikson, and Antonio Schizzerotto. 2017. 'Linking the Macro to the Micro: A Multidimensional Approach to Educational Inequalities in Four European Countries'. European Societies, 1-39. https://doi.org/10.1080/14616696.2017.1329934.

Bukodi, Erzsébet, Marii Paskov, and Brian Nolan. 2019. 'Intergenerational Class Mobility in Europe: A New Account'. Social Forces, April. https://doi.org/10.1093/sf/soz026.

Clark, Andrew. 2003. 'Unemployment as a Social Norm: Psychological Evidence from Panel Data'. Journal of Labor Economics 21 (2): 323-51. https:/ /doi.org/10.1086/345560.

Clasen, Jochen, and Daniel Clegg. 2006. 'BEYOND ACTIVATION REFORMING EUROPEAN UNEMPLOYMENT PROTECTION SYSTEMS IN POST-INDUSTRIAL LABOUR MARKETS'. European Societies 8 (4): 527-53. https://doi.org/10.1080/14616690601002582.

Coelli, Michael B. 2011. 'Parental Job Loss and the Education Enrollment of Youth'. Labour Economics 18 (1): 25-35. https://doi.org/10.1016/j.labeco.2010.04.015.

Der Spiegel. 2020. 'Grüne Wollen Hartz IV Grundlegend Verändern', 2020. https://www.spiegel.de/politik/deutschland/gruene-wollen-hartz-iv-grundlegendveraendern-a-41c1af5e-6f19-47ec-8dc5-9ec51aef78c8.

Der Tagesspiegel. 2019. 'Sanktionen Sind Teilweise Verfassungswidrig', 2019. https://www.tagesspiegel.de/politik/hartz-iv-urteil-sanktionen-sind-teilweiseverfassungswidrig/25183746.html.

Deter, Max. 2020. 'Hartz and Minds: Happiness Effects of Reforming an Employment Agency'. Journal of Happiness Studies, July. https:/ / doi.org/10.1007/s10902-020-00297-7.

Duncan, Greg, and Jeanne Brooks-Gunn, eds. 1997. Consequences of Growing up Poor. New York: Russell Sage Foundation.

Eichhorst, Werner, and Paul Marx. 2011. 'Reforming German Labour Market Institutions: A Dual Path to Flexibility'. Journal of European Social Policy 21 (1): 73-87. https://doi.org/10.1177/0958928710385731.

Ermisch, John, Markus Jäntti, and Timothy M. Smeeding, eds. 2012. From Parents to Children: The Intergenerational Transmission of Advantage. New York: Russell Sage Foundation.

Esping-Andersen, Gøsta. 1990. The Three Worlds of Welfare Capitalism. Cambridge, UK: Polity Press. . 2014. 'Welfare Regimes and Social Stratification'. Journal of European Social Policy 25 (1): 124-34. https://doi.org/10.1177/0958928714556976.

Farkas, George. 2003. 'Cognitive Skills and Noncognitive Traits and Behaviors in Stratification Processes'. Annual Review of Sociology 29 (1): 541-62. https://doi.org/10.1146/annurev.soc.29.010202.100023.

Fohrbeck, Anna, Andreas Hirseland, and Philipp Ramos Lobato. 2014. 'How Benefits Recipients Perceive Themselves through the Lens of the Mass Media - Some Observations from Germany'. Sociological Research Online 19 (4): 74-81. https://doi.org/10.5153/sro.3524.

Goebel, Jan, and Maria Richter. 2007. 'Nach Der Einführung von Arbeitslosengeld II: Deutlich Mehr Verlierer Als Gewinner Unter Den Hilfeempfängern'. DIW Wochenbericht 74 (50): 753 62.

Hassel, Anke, and Christof Schiller. 2010. 'Die Politische Dynamik von Arbeitsmarktreformen in Deutschland Am Beispiel Der Hartz IV-Reform’. Abschlussbericht. 
Hertweck, Matthias, and Oliver Sigrist. 2012. 'The Aggregate Effects of the Hartz Reforms in Germany'. University of Konstan ₹.W orking Paper 38.

Hochmuth, Brigitte, Britta Kohlbrecher, Christian Merkl, and Hermann Gartner. 2021. 'Hartz IV and the Decline of German Unemployment: A Macroeconomic Evaluation'. Journal of Economic Dynamics and Control 127 (June): 104114. https://doi.org/10.1016/j.jedc.2021.104114.

Jacobi, Lena, and Jochen Kluve. 2006. 'Before and After the Hartz Reforms: The Performance of Active Labour Market Policy in Germany’. IZA Discussion Paper No. 2100.

Jaeger, M. M. 2009. 'Equal Access but Unequal Outcomes: Cultural Capital and Educational Choice in a Meritocratic Society'. Social Forces 87 (4): 1943-71. https://doi.org/10.1353/sof.0.0192.

Kalil, Ariel, and Patrick Wightman. 2011. 'Parental Job Loss and Children's Educational Attainment in Black and White Middle-Class Families*: Job Loss and Children's Educational Attainment'. Social Science Quarterly 92 (1): 57-78. https://doi.org/10.1111/j.15406237.2011.00757.x.

Kaushal, Neeraj, Katherine Magnuson, and Jane Waldfogel. 2011. 'How Is Family Income Related to Investments in Children's Learning?' In Whither Opportunity? Rising Inequality and the Uncertain Life Chances of Low-Income Children, edited by Richard Murnane and Greg J. Duncan, 187-206. New York: Russell Sage Foundation.

Krause, Michael U., and Harald Uhlig. 2012. 'Transitions in the German Labor Market: Structure and Crisis'. Journal of Monetary Economics 59 (1): 64-79. https://doi.org/10.1016/j.jmoneco.2011.10.003.

Launov, Andrey, and Klaus Wälde. 2013. 'Estimating Incentive and Welfare Effects of Nonstationary Unemployment Benefits'. International Economic Review 54 (4): 1159-98. https://doi.org/10.1111/iere.12032.

Lindemann, Kristina, and Markus Gangl. 2019. 'The Intergenerational Effects of Unemployment: How Parental Unemployment Affects Educational Transitions in Germany'. Research in Social Stratification and Mobility 62 (August): 100410. https://doi.org/10.1016/j.rssm.2019.100410.

. 2020. 'Parental Unemployment and the Transition into Tertiary Education: Can Institutions Moderate the Adverse Effects?' Social Forces 99 (2): 616-47. https://doi.org/10.1093/sf/soz155.

Lohmann, Henning, and Olaf Groh-Samberg. 2017. 'Elterliche Arbeitslosigkeitsdynamiken und Bildungsverläufe vom Ende der Grundschulzeit bis zum jungen Erwachsenenalter'. KZfSS Kölner Zeitschrift für Soziologie und Sozialpsychologie 69 (4): 623-50. https://doi.org/10.1007/s11577-017-0487-5.

Mood, C. 2010. 'Logistic Regression: Why We Cannot Do What We Think We Can Do, and What We Can Do About It'. European Sociological Review 26 (1): 67-82. https://doi.org/10.1093/esr/jcp006.

Murray, Lynne, Matt Woolgar, Carla Martins, Anna Christaki, Alison Hipwell, and Peter Cooper. 2006. 'Conversations around Homework: Links to Parental Mental Health, Family Characteristics and Child Psychological Functioning'. British Journal of Developmental Psychology 24 (1): 125-49. https://doi.org/10.1348/026151005X83568.

Neugebauer, Martin, David Reimer, Steffen Schindler, and Volker Stocké. 2013. 'Inequality in Transitions to Secondary School and Tertiary Education in Germany'. In Determined to Succeed?, edited by Michelle Jackson, 56-88. Stanford University Press. https://doi.org/10.11126/stanford/9780804783026.003.0003. 
Oesch, Daniel, and Oliver Lipps. 2013. 'Does Unemployment Hurt Less If There Is More of It Around? A Panel Analysis of Life Satisfaction in Germany and Switzerland'. European Sociological Review 29 (5): 955-67. https://doi.org/10.1093/esr/jcs071.

Palier, Bruno, and Kathleen Thelen. 2010. 'Institutionalizing Dualism: Complementarities and Change in France and Germany'. Politics \& Society 38 (1): 119-48. https://doi.org/10.1177/0032329209357888.

Pischke, Jörn-Steffen, and Till von Wachter. 2008. 'Zero Returns to Compulsory Schooling in Germany: Evidence and Interpretation'. The Review of Economics and Statistics 90 (3): 592-98.

Pollak, Reinhard, and Walter Müller. 2020. 'Education as an Equalizing Force: How Declining Educational Inequality and Educational Expansion Have Contributed to More Social Fluidity in Germany'. In Education and Intergenerational Social Mobility in Europe and the United States, edited by Richard Breen and Walter Müller, 122-49. Stanford, California: Stanford University Press.

Shavit, Yossi, and Hans-Peter Blossfeld, eds. 1993. Persistent Inequality: Changing Educational Attainment in Thirteen Countries. Social Inequality Series. Boulder, Colo: Westview Press.

Sturgis, Patrick, and Franz Buscha. 2015. 'Increasing Inter-Generational Social Mobility: Is Educational Expansion the Answer?: Increasing Inter-Generational Social Mobility'. The British Journal of Sociology 66 (3): 512-33. https://doi.org/10.1111/1468-4446.12138.

Süddeutsche Zeitung. 2019. 'Der Abschied von Hartz IV Ist Ein Nötiger Neuanfang', 2019. https://www.sueddeutsche.de/wirtschaft/pro-und-contra-zur-sozialen-wende-der-spd-derabschied-von-hartz-iv-ist-ein-noetiger-neuanfang-1.4325088. 
Table 1. Unemployment and social benefit schemes before and after the Hartz IV reform

\begin{tabular}{|c|c|c|c|c|c|c|}
\hline & & Pre-reform & & & Post-reform & \\
\hline & Arbeitslosengeld & Arbeitslosenhilfe & Sozialhilfe & Arbeitslosengeld & Arbeitslosengeld II & Sozialhilfe \\
\hline Main aim & Status maintenance & Status maintenance & Poverty alleviation & Status maintenance & Poverty alleviation & Poverty alleviation \\
\hline Benefit type & $\begin{array}{c}\text { Earnings-related } \\
\text { individual-level benefit }\end{array}$ & $\begin{array}{c}\text { Earnings-related } \\
\text { individual-level benefit }\end{array}$ & $\begin{array}{c}\text { Flat-rate } \\
\text { household-level benefit }\end{array}$ & $\begin{array}{c}\text { Earnings-related } \\
\text { individual-level benefit }\end{array}$ & $\begin{array}{c}\text { Flat-rate } \\
\text { household-level benefit }\end{array}$ & $\begin{array}{c}\text { Flat-rate } \\
\text { household-level benefit }\end{array}$ \\
\hline Eligibility & $\begin{array}{l}\text { Unemployed with social } \\
\text { insurance contributions }\end{array}$ & $\begin{array}{l}\text { Unemployed who } \\
\text { received Arbeitslosengeld }\end{array}$ & Individuals in need & $\begin{array}{l}\text { Unemployed with social } \\
\text { insurance contributions }\end{array}$ & $\begin{array}{l}\text { Individuals in need } \\
\text { who are able to work }\end{array}$ & $\begin{array}{c}\text { Individuals in need } \\
\text { who are unable to work }\end{array}$ \\
\hline Benefit level & $\begin{array}{c}60 \text { percent } \\
\text { (67 percent w/children) } \\
\text { of previous earnings }\end{array}$ & $\begin{array}{c}53 \text { percent } \\
\text { (57 percent w/children) } \\
\text { of previous earnings }\end{array}$ & $\begin{array}{l}\text { Socio-cultural } \\
\text { subsistence level }\end{array}$ & $\begin{array}{c}60 \text { percent } \\
\text { (67 percent w/children) } \\
\text { of previous earnings }\end{array}$ & $\begin{array}{l}\text { Socio-cultural } \\
\text { subsistence level }\end{array}$ & $\begin{array}{l}\text { Socio-cultural } \\
\text { subsistence level }\end{array}$ \\
\hline Max. duration & $\begin{array}{l}12 \text { months if age }<45 \\
18 \text { months if age } 45-56 \\
36 \text { months if age }>56\end{array}$ & $\mathrm{n} / \mathrm{a}$ & $\mathrm{n} / \mathrm{a}$ & $\begin{array}{l}12 \text { months if age }<55 \\
18 \text { months if age }>54\end{array}$ & $\mathrm{n} / \mathrm{a}$ & $\mathrm{n} / \mathrm{a}$ \\
\hline Sanctions & $\mathrm{n} / \mathrm{a}$ & Moderate & Strict & $\mathrm{n} / \mathrm{a}$ & Strict & $\mathrm{n} / \mathrm{a}$ \\
\hline
\end{tabular}

Note: Own illustration based on Bäcker and Koch (2004), Boucarde (2007), Hassel and Schiller (2010). White-shaded area indicates unemployment insurance schemes, while grey-shaded area indicates poverty relief scheme. 
Table 2. Descriptives

\begin{tabular}{|c|c|c|c|c|c|c|c|c|c|}
\hline & \multicolumn{2}{|c|}{$\begin{array}{l}\text { Pre-reform } \\
(2000-2004)\end{array}$} & \multicolumn{2}{|c|}{$\begin{array}{l}\text { Post-reform } \\
(2005-2009)\end{array}$} & & \multicolumn{2}{|c|}{$\begin{array}{l}\text { Pre-reform } \\
(2000-2004)\end{array}$} & \multicolumn{2}{|c|}{$\begin{array}{l}\text { Post-reform } \\
(2005-2009)\end{array}$} \\
\hline & $\% /$ Mean & $\mathrm{SD}$ & $\% /$ Mean & $\mathrm{SD}$ & & $\% /$ Mean & SD & $\% /$ Mean & SD \\
\hline Secondary school & & & & & Parental characteristics & & & & \\
\hline Gymnasium & 33.40 & & 38.66 & & Benefit receipt & & & & \\
\hline Year started secondary school & & & & & No benefit receipt & 86.43 & & 87.39 & \\
\hline 2001 & 24.83 & & & & Unemployment benefits & 4.88 & & 3.19 & \\
\hline 2002 & 19.26 & & & & Unemployment assistance & 5.25 & & 2.61 & \\
\hline 2003 & 20.26 & & & & Social assistance & 3.44 & & 6.81 & \\
\hline 2004 & 17.76 & & & & & & & & \\
\hline 2005 & 17.89 & & & & & & & & \\
\hline 2006 & & & 24.03 & & Education & & & & \\
\hline 2007 & & & 22.86 & & Low & 26.89 & & 22.02 & \\
\hline 2008 & & & 20.59 & & Medium & 31.96 & & 34.20 & \\
\hline 2009 & & & 16.47 & & High & 41.15 & & 43.78 & \\
\hline 2010 & & & 16.05 & & & & & & \\
\hline Federal state of secondary school & & & & & Social class & & & & \\
\hline Schleswig-Holstein & 3.00 & & 2.35 & & Salariat & 41.84 & & 47.56 & \\
\hline Hamburg & 1.25 & & 1.60 & & Intermediate class & 24.89 & & 25.63 & \\
\hline Niedersachsen & 10.44 & & 10.00 & & Working class & 30.83 & & 24.37 & \\
\hline Bremen & 0.44 & & 0.50 & & Never worked & 2.44 & & 2.44 & \\
\hline Nordrhein-Westfalen & 20.76 & & 21.76 & & & & & & \\
\hline Hessen & 7.44 & & 8.40 & & & & & & \\
\hline Rheinland-Pfalz & 6.94 & & 6.64 & & Self-rated health & & & & \\
\hline Baden-Wuerttemberg & 14.57 & & 14.29 & & Very good & 5.38 & & 5.21 & \\
\hline Bayern & 17.01 & & 16.89 & & Good & 42.71 & & 42.69 & \\
\hline Saarland & 1.38 & & 1.09 & & Satisfactory & 37.65 & & 35.38 & \\
\hline Berlin & 2.81 & & 1.68 & & Poor & 12.38 & & 14.12 & \\
\hline Brandenburg & 3.69 & & 2.44 & & $\mathrm{Bad}$ & 1.88 & & 2.61 & \\
\hline Mecklenburg-Vorpommern & 1.50 & & 1.51 & & & & & & \\
\hline Sachsen & 3.75 & & 5.63 & & & & & & \\
\hline Sachsen-Anhalt & 2.63 & & 2.10 & & Age & 40.67 & 5.65 & 41.56 & 5.44 \\
\hline Thueringen & 2.38 & & 3.11 & & Life satisfaction & 6.66 & 1.69 & 6.62 & 1.72 \\
\hline Child characteristics & & & & & Household characteristics & & & & \\
\hline Age at transition to secondary school & 10.61 & 0.77 & 10.45 & 0.70 & Number of children age $0-14$ & 1.90 & 0.86 & 1.87 & 0.87 \\
\hline Female & 48.59 & & 48.40 & & Single parent & 8.82 & & 12.18 & \\
\hline Migrant background & 27.64 & & 27.90 & & Log net income $(2000 €)$ & 9.68 & 0.47 & 9.70 & 0.48 \\
\hline $\mathrm{N}$ & 1,599 & & 1,190 & & $\mathrm{~N}$ & 1,599 & & 1,190 & \\
\hline
\end{tabular}


Table 3. Gymnasium attendance by parental benefit receipt, before and after reform (OLS)

\begin{tabular}{|c|c|c|c|c|c|}
\hline & (1) & $(2)$ & (3) & (4) & (5) \\
\hline Reform & $\begin{array}{c}0.062^{* *} \\
(0.024)\end{array}$ & $\begin{array}{c}0.426^{* * *} \\
(0.136)\end{array}$ & $\begin{array}{l}0.143 \\
(0.658)\end{array}$ & $\begin{array}{c}-0.398 \\
(0.837)\end{array}$ & $\begin{array}{c}-0.430 \\
(0.844)\end{array}$ \\
\hline Unemployment benefits & $\begin{array}{c}-0.181^{* * *} \\
(0.046)\end{array}$ & $\begin{array}{c}-0.147^{* * *} \\
(0.056)\end{array}$ & $\begin{array}{c}-0.081 \\
(0.050)\end{array}$ & $\begin{array}{c}-0.073 \\
(0.049)\end{array}$ & $\begin{array}{c}-0.070 \\
(0.049)\end{array}$ \\
\hline Unemployment assistance & $\begin{array}{c}-0.180^{* * *} \\
(0.053)\end{array}$ & $\begin{array}{c}-0.092 \\
(0.066)\end{array}$ & $\begin{array}{l}0.037 \\
(0.068)\end{array}$ & $\begin{array}{l}0.071 \\
(0.068)\end{array}$ & $\begin{array}{l}0.077 \\
(0.068)\end{array}$ \\
\hline Social assistance & $\begin{array}{c}-0.227^{* * *} \\
(0.049)\end{array}$ & $\begin{array}{c}-0.292^{* * *} \\
(0.034)\end{array}$ & $\begin{array}{r}-0.121^{* *} \\
(0.047)\end{array}$ & $\begin{array}{r}-0.097^{* *} \\
(0.048)\end{array}$ & $\begin{array}{r}-0.094^{* *} \\
(0.047)\end{array}$ \\
\hline Reform $\times$ Unemployment benefits & & $\begin{array}{c}-0.108 \\
(0.090)\end{array}$ & $\begin{array}{c}-0.102 \\
(0.098)\end{array}$ & $\begin{array}{c}-0.086 \\
(0.099)\end{array}$ & $\begin{array}{c}-0.085 \\
(0.097)\end{array}$ \\
\hline Reform $\times$ Unemployment assistance & & $\begin{array}{c}-0.249^{* * *} \\
(0.082)\end{array}$ & $\begin{array}{r}-0.216^{* *} \\
(0.089)\end{array}$ & $\begin{array}{c}-0.116 \\
(0.095)\end{array}$ & $\begin{array}{c}-0.119 \\
(0.095)\end{array}$ \\
\hline Reform $\times$ Social assistance & & $\begin{array}{l}0.096 \\
(0.081)\end{array}$ & $\begin{array}{l}0.067 \\
(0.087)\end{array}$ & $\begin{array}{l}0.117 \\
(0.089)\end{array}$ & $\begin{array}{l}0.116 \\
(0.089)\end{array}$ \\
\hline Log $\mathrm{HH}$ income & & & & $\begin{array}{r}0.131^{* * * *} \\
(0.030)\end{array}$ & $\begin{array}{r}0.125^{* * *} \\
(0.030)\end{array}$ \\
\hline Reform $\times$ Log $\mathrm{HH}$ income & & & & $\begin{array}{l}0.056 \\
(0.053)\end{array}$ & $\begin{array}{l}0.057 \\
(0.053)\end{array}$ \\
\hline Parental life satisfaction & & & & & $\begin{array}{l}0.008 \\
(0.008)\end{array}$ \\
\hline Reform $\times$ Parental life satisfaction & & & & & $\begin{array}{l}0.001 \\
(0.013)\end{array}$ \\
\hline Year and state fixed-effects & Yes & Yes & Yes & Yes & Yes \\
\hline Socio-demographic controls & No & No & Yes & Yes & Yes \\
\hline $\mathrm{N}$ & 2,789 & 2,789 & 2,789 & 2,789 & 2,789 \\
\hline \multicolumn{6}{|c|}{$\begin{array}{l}* \mathrm{p}<0.10, * * \mathrm{p}<0.05, * * * \mathrm{p}<0.01 \text {. Pre-treatment period } 2000-2004 \text {, post-treatment period: } 2005-2009 \text {. Reference } \\
\text { category is 'No benefits'. Cross-sectional weights applied. Robust standard errors in parentheses. Socio-demographic } \\
\text { controls include child's age at transition, sex, migration background, number of children age } 0-14 \text { in the household, } \\
\text { living with single parent, parental age(-squared), parental education, parental social class, parental self-rated health. } \\
\text { SOEP v.34. }\end{array}$} \\
\hline
\end{tabular}


Figure 1. Differences in probability to attend Gymnasium for children of unemployment assistance recipients relative to children whose parents do not receive benefits, before and after reform

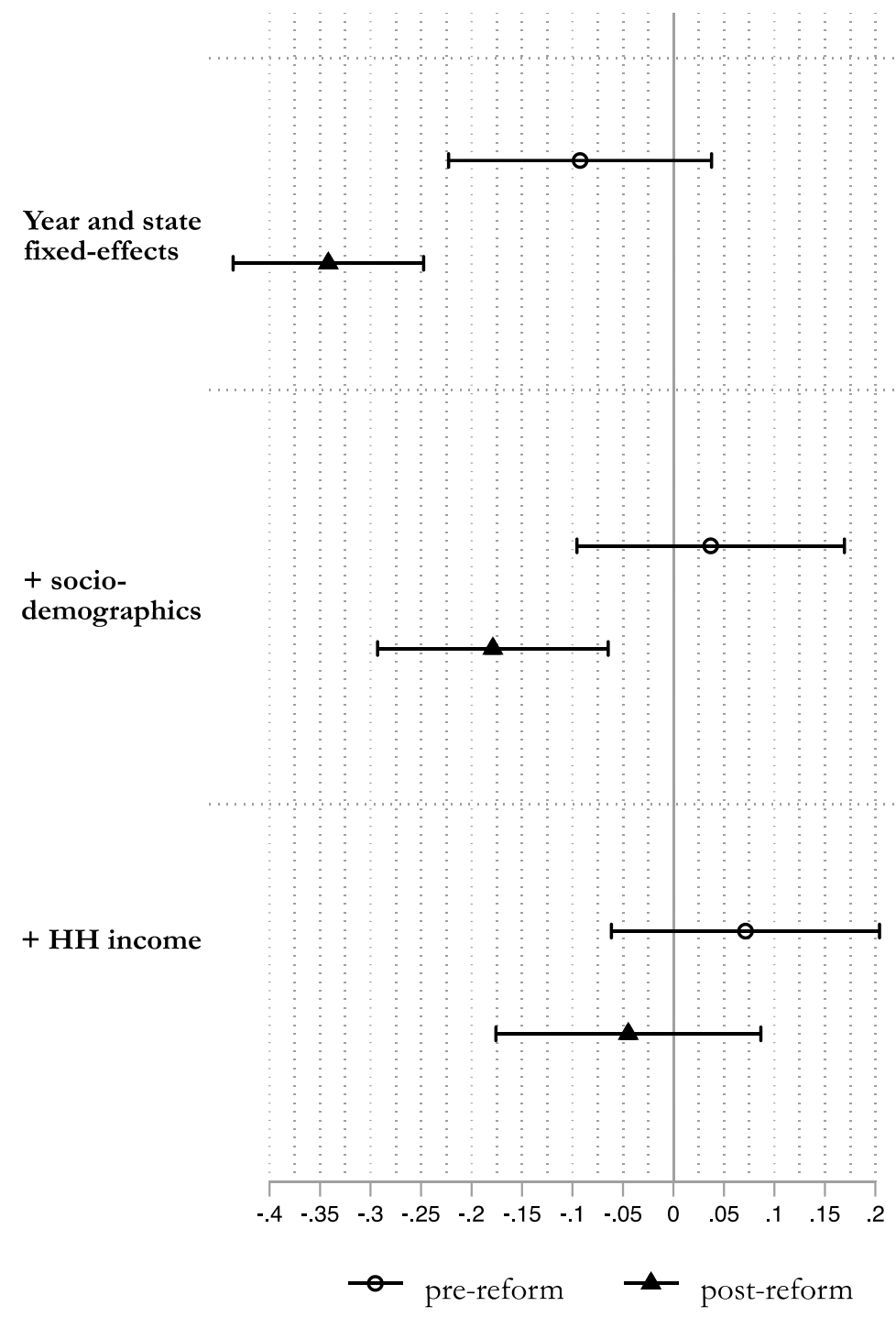

Note: Based on Table 3, columns 2-4. 95 percent confidence intervals shown. 


\section{APPENDIX}

Table A1. Gymnasium attendance by parental benefit receipt, before and after reform (Logit)

\begin{tabular}{|c|c|c|c|c|c|}
\hline & (1) & $(2)$ & (3) & (4) & (5) \\
\hline Reform & $\begin{array}{r}0.294^{* * *} \\
(0.114)\end{array}$ & $\begin{array}{r}2.031^{* * *} \\
(0.666)\end{array}$ & $\begin{array}{l}1.181 \\
(3.914)\end{array}$ & $\begin{array}{c}-0.764 \\
(5.258)\end{array}$ & $\begin{array}{c}-1.206 \\
(5.294)\end{array}$ \\
\hline Unemployment benefits & $\begin{array}{c}-0.991^{* * *} \\
(0.316)\end{array}$ & $\begin{array}{r}-0.792^{* *} \\
(0.354)\end{array}$ & $\begin{array}{c}-0.428 \\
(0.351)\end{array}$ & $\begin{array}{c}-0.363 \\
(0.347)\end{array}$ & $\begin{array}{c}-0.349 \\
(0.349)\end{array}$ \\
\hline Unemployment assistance & $\begin{array}{r}-0.965^{* * *} \\
(0.353)\end{array}$ & $\begin{array}{c}-0.487 \\
(0.376)\end{array}$ & $\begin{array}{l}0.199 \\
(0.433)\end{array}$ & $\begin{array}{l}0.459 \\
(0.434)\end{array}$ & $\begin{array}{l}0.495 \\
(0.437)\end{array}$ \\
\hline Social assistance & $\begin{array}{c}-1.281^{* * *} \\
(0.378)\end{array}$ & $\begin{array}{r}-2.686^{* * *} \\
(0.749)\end{array}$ & $\begin{array}{c}-1.596^{*} \\
(0.846)\end{array}$ & $\begin{array}{c}-1.358 \\
(0.872)\end{array}$ & $\begin{array}{c}-1.329 \\
(0.877)\end{array}$ \\
\hline Reform $\times$ Unemployment benefits & & $\begin{array}{c}-0.717 \\
(0.698)\end{array}$ & $\begin{array}{l}-0.918 \\
(0.853)\end{array}$ & $\begin{array}{c}-0.954 \\
(0.856)\end{array}$ & $\begin{array}{c}-0.889 \\
(0.834)\end{array}$ \\
\hline Reform $\times$ Unemployment assistance & & $\begin{array}{r}-1.823^{* *} \\
(0.752)\end{array}$ & $\begin{array}{c}-1.919^{* *} \\
(0.890)\end{array}$ & $\begin{array}{r}-1.508^{*} \\
(0.871)\end{array}$ & $\begin{array}{r}-1.495^{*} \\
(0.870)\end{array}$ \\
\hline Reform $\times$ Social assistance & & $\begin{array}{l}1.696^{*} \\
(0.871)\end{array}$ & $\begin{array}{l}1.125 \\
(0.978)\end{array}$ & $\begin{array}{l}1.358 \\
(1.007)\end{array}$ & $\begin{array}{l}1.357 \\
(1.015)\end{array}$ \\
\hline Log $\mathrm{HH}$ income & & & & $\begin{array}{r}0.845^{* * *} \\
(0.206)\end{array}$ & $\begin{array}{r}0.806^{* * *} \\
(0.209)\end{array}$ \\
\hline Reform $\times$ Log $\mathrm{HH}$ income & & & & $\begin{array}{l}0.212 \\
(0.340)\end{array}$ & $\begin{array}{l}0.218 \\
(0.342)\end{array}$ \\
\hline Parental life satisfaction & & & & & $\begin{array}{l}0.049 \\
(0.054)\end{array}$ \\
\hline Reform $\times$ Parental life satisfaction & & & & & $\begin{array}{l}0.028 \\
(0.082)\end{array}$ \\
\hline Year and state fixed-effects & Yes & Yes & Yes & Yes & Yes \\
\hline Socio-demographic controls & No & No & Yes & Yes & Yes \\
\hline $\mathrm{N}$ & 2,789 & 2,789 & 2,786 & 2,786 & 2,786 \\
\hline
\end{tabular}

${ }^{*} \mathrm{p}<0.10, * * \mathrm{p}<0.05,{ }^{*} * * \mathrm{p}<0.01$. Pre-treatment period 2000-2004, post-treatment period: 2005-2009. Reference category is 'No benefits'. Cross-sectional weights applied. Robust standard errors in parentheses. Socio-demographic controls include child's age at transition, sex, migration background, number of children age 0-14 in the household, living with single parent, parental age(-squared), parental education, parental social class, parental self-rated health. SOEP v.34. 
Table A2. Gymnasium attendance by parental benefit receipt, before reform (OLS)

\begin{tabular}{|c|c|c|c|}
\hline & $(1)$ & $(2)$ & (3) \\
\hline Unemployment benefits & $-0.147^{* * *}(0.056)$ & $-0.081(0.094)$ & $-0.013(0.111)$ \\
\hline Unemployment assistance & $-0.092(0.066)$ & $-0.099(0.139)$ & $0.007(0.124)$ \\
\hline Social assistance & $-0.292^{* * *}(0.033)$ & $-0.303^{* * *}(0.037)$ & $-0.101(0.074)$ \\
\hline 2001 & $-0.010(0.040)$ & $-0.007(0.044)$ & $0.018(0.042)$ \\
\hline 2002 & $0.019(0.041)$ & $0.027(0.047)$ & $0.019(0.041)$ \\
\hline 2003 & $0.009(0.041)$ & $0.006(0.045)$ & $0.007(0.042)$ \\
\hline 2004 & $0.094^{* *}(0.045)$ & $0.094^{*}(0.051)$ & $0.063(0.044)$ \\
\hline Unemployment benefits $\times 2001$ & & $0.018(0.175)$ & $-0.010(0.187)$ \\
\hline Unemployment benefits $\times 2002$ & & $-0.116(0.148)$ & $-0.143(0.147)$ \\
\hline Unemployment benefits $\times 2003$ & & $0.009(0.188)$ & $-0.015(0.170)$ \\
\hline Unemployment benefits $\times 2004$ & & $-0.125(0.137)$ & $-0.083(0.139)$ \\
\hline Unemployment assistance $\times 2001$ & & $-0.132(0.147)$ & $-0.092(0.138)$ \\
\hline Unemployment assistance $\times 2002$ & & $-0.024(0.177)$ & $0.013(0.175)$ \\
\hline Unemployment assistance $\times 2003$ & & $-0.009(0.184)$ & $-0.048(0.172)$ \\
\hline Unemployment assistance $\times 2004$ & & $0.127(0.202)$ & $0.168(0.190)$ \\
\hline Social assistance $\times 2001$ & & $0.096(0.107)$ & $-0.010(0.121)$ \\
\hline Social assistance $\times 2002$ & & $0.002(0.054)$ & $-0.018(0.089)$ \\
\hline Social assistance $\times 2003$ & & $0.073(0.112)$ & $-0.011(0.127)$ \\
\hline Social assistance $\times 2004$ & & $-0.100^{*}(0.059)$ & $-0.063(0.082)$ \\
\hline State fixed-effects & Yes & Yes & Yes \\
\hline Socio-demographic controls & No & No & Yes \\
\hline $\mathrm{N}$ & 1,599 & 1,599 & 1,599 \\
\hline
\end{tabular}

${ }^{*} \mathrm{p}<0.10,{ }^{* *} \mathrm{p}<0.05,{ }^{* * *} \mathrm{p}<0.01$. Testing for non-parallel trends during pre-treatment period 2000-2004. Robust standard errors in parentheses. Reference categories are 'No benefit' and '2000'. Cross-sectional weights applied. Sociodemographic controls include child's age at transition, sex, migration background, number of children age 0-14 in the household, living with single parent, parental age(-squared), parental education, parental social class, parental self-rated health. SOEP v.34. 
Table A3. Gymnasium attendance by parental benefit receipt, placebo tests (OLS)

\begin{tabular}{|c|c|c|c|c|c|c|}
\hline & (1) & (2) & (3) & (4) & (5) & (6) \\
\hline Reform & $\begin{array}{l}-0.014 \\
(0.026)\end{array}$ & $\begin{array}{l}-0.025 \\
(0.125)\end{array}$ & $\begin{array}{l}-0.379 \\
(0.706)\end{array}$ & $\begin{array}{l}0.017 \\
(0.029)\end{array}$ & $\begin{array}{c}-0.129 \\
(0.169)\end{array}$ & $\begin{array}{l}0.604 \\
(0.761)\end{array}$ \\
\hline Unemployment benefits & $\begin{array}{r}-0.181^{* * *} \\
(0.044)\end{array}$ & $\begin{array}{r}-0.219^{* * *} \\
(0.051)\end{array}$ & $\begin{array}{r}-0.125^{* *} \\
(0.051)\end{array}$ & $\begin{array}{r}-0.278^{* * *} \\
(0.055)\end{array}$ & $\begin{array}{r}-0.266^{* * *} \\
(0.075)\end{array}$ & $\begin{array}{r}-0.183^{* *} \\
(0.091)\end{array}$ \\
\hline Unemployment assistance & $\begin{array}{r}-0.119^{* *} \\
(0.051)\end{array}$ & $\begin{array}{c}-0.114^{*} \\
(0.067)\end{array}$ & $\begin{array}{l}0.005 \\
(0.069)\end{array}$ & $\begin{array}{r}-0.355^{* * *} \\
(0.045)\end{array}$ & $\begin{array}{r}-0.324^{* * *} \\
(0.060)\end{array}$ & $\begin{array}{r}-0.181^{* * *} \\
(0.067)\end{array}$ \\
\hline Social assistance & $\begin{array}{r}-0.286^{* * *} \\
(0.033)\end{array}$ & $\begin{array}{c}-0.286^{* * *} \\
(0.039)\end{array}$ & $\begin{array}{r}-0.221^{* *} \\
(0.100)\end{array}$ & $\begin{array}{c}-0.257^{* * *} \\
(0.044)\end{array}$ & $\begin{array}{r}-0.245^{* * *} \\
(0.073)\end{array}$ & $\begin{array}{c}-0.101 \\
(0.077)\end{array}$ \\
\hline Reform $\times$ Unemployment benefits & & $\begin{array}{l}0.058 \\
(0.081)\end{array}$ & $\begin{array}{l}0.035 \\
(0.075)\end{array}$ & & $\begin{array}{l}-0.023 \\
(0.114)\end{array}$ & $\begin{array}{l}0.009 \\
(0.140)\end{array}$ \\
\hline Reform $\times$ Unemployment assistance & & $\begin{array}{l}0.017 \\
(0.100)\end{array}$ & $\begin{array}{l}0.038 \\
(0.103)\end{array}$ & & $\begin{array}{c}-0.083 \\
(0.077)\end{array}$ & $\begin{array}{c}-0.076 \\
(0.098)\end{array}$ \\
\hline Reform $\times$ Social assistance & & $\begin{array}{l}0.002 \\
(0.055)\end{array}$ & $\begin{array}{l}0.115 \\
(0.114)\end{array}$ & & $\begin{array}{c}-0.023 \\
(0.091)\end{array}$ & $\begin{array}{l}0.042 \\
(0.095)\end{array}$ \\
\hline Year and state fixed-effects & Yes & Yes & Yes & Yes & Yes & Yes \\
\hline Socio-demographic controls & No & No & Yes & No & No & Yes \\
\hline $\mathrm{N}$ & 2,309 & 2,309 & 2,309 & 3,039 & 3,039 & 3,039 \\
\hline
\end{tabular}

$* \mathrm{p}<0.10, * * \mathrm{p}<0.05,{ }^{* * *} \mathrm{p}<0.01$. Columns (1)-(3): Pre-treatment period 1997-2000, post-treatment period: $2001-2004$. Columns (4)-(6): Pre-treatment period 2005-2008, post-treatment period: 2009-2012. Reference category is 'No benefits'. Cross-sectional weights applied. Robust standard errors in parentheses. Socio-demographic controls include child's age at transition, sex, migration background, number of children age 0-14 in the household, living with single parent, parental age(-squared), parental education, parental social class, parental self-rated health. SOEP v.34 
Figure A1. Quasi-experimental study design

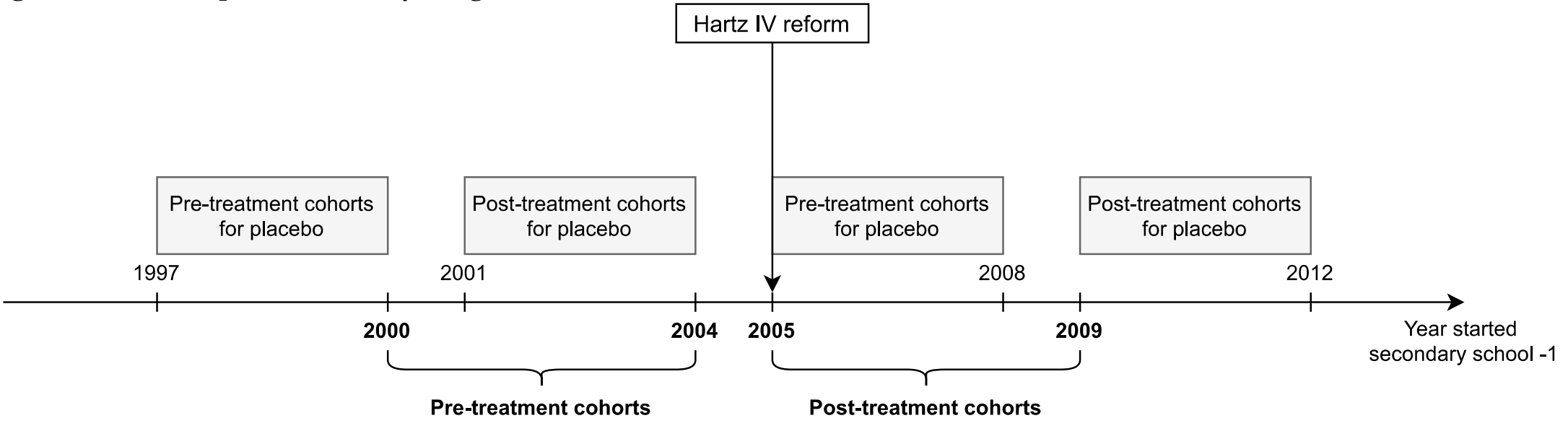

